\title{
Renata CZEKALSKA
}

Jagiellonian University in Kraków, Poland

r.czekalska@uj.edu.pl

\section{THE WONDER OF INSPIRATION: \\ MUSICAL UNIVERSALIZATIONS \\ OF RABINDRANATH TAGORE'S POEMS \\ IN POLISH CULTURE}

ABSTRACT The paper presents select distinctive results of Polish fascination with the poetry of Rabindranath Tagore, placing this phenomenon in the sphere of universalization within the syntagma of Polish national culture. The translations of Tagore's poetry are presented as the first stage of the process of intercultural communication, based on the understanding of these literary works in the allegorical and symbolic styles of reception. Subsequently, the literary translations are perceived in the style of aesthetization. This style of reception of a work of art induces the occurrence of transcriptions of literary works - from the sign system of language into the sign system of music. Musical compositions found in contemporary Polish music are examples of concretizations of literary works.

Keywords: intercultural communication; intrinsic values; concretization of a literary work; reception of Tagore in Poland. 


\section{INTRODUCTORY REMARKS}

The aim of this article is to present and discuss particular cases of bringing poetic works back to life in a creative manner. It is a result of a broader study of intercultural inspirations or - to cite Antonina Kłoskowska - of the presence of components of a genetically different culture in the syntagma of a national culture. In the case of this study, the area of research includes the syntagma of Polish culture, and the instances of the foreign components - here: Indian - are chosen from among the results of the Polish fascination with the poetry of Rabindranath Tagore.

All the examples of literary symbolic actions, undertaken in the sphere of universalization of the Polish cultural syntagma and described in the article, are testimonies of the culture-creative features of intrinsic values. Therefore, the main thesis of the article is based on the assumption that the existence of such features results in the mutual enrichment of both the cultures, e.g. Polish and Indian, in spite of the geographical as well as civilizational distance between them.

The theoretical foundation for the current observations is based on Antonina Kłoskowska's concept of the syntagma of national cultural, Michał Głowiński's classification of styles and methods of reception, Roman Ingarden's notion of concretization, and Władysław Strózewski's definition of inspiration.

The core of the article is divided into five parts. The first, titled The sphere of intercultural contacts in the syntagma of a national culture, presents a very brief recapitulation of Kłoskowska's syntagma of the concept of national culture, and places the works of Rabindranath Tagore within the Polish cultural syntagma. Part two, Translations as symptoms of literary reception, focuses on theoretical references to Głowiński's idea of methods and styles of reception with regard to the treatment of Tagore's poetry in Poland. Part three, From reception to concretization, includes references to Roman Ingarden's concept of concretization of a literary work, and describes the bridging process that leads to perceiving a work of art in a creative manner. The fourth part, Musical concretizations of Tagore's poems, is devoted to examples of works by Polish composers inspired by the poetry of Tagore, while the fifth part, The universalizing power of inspiration, places the discussed instances of artistic transformations in the sphere of universalization, in the Polish cultural syntagma.

\section{THE SPHERE OF INTERCULTURAL CONTACTS IN THE SYNTAGMA OF A NATIONAL CULTURE}

In her book National Cultures at the Grass-Root Level, an eminent Polish sociologist, Antonina Kłoskowska (1919-2001), stated that Every developed nation builds its own culture and recognizes it as its own in contacts with other nations..., ${ }^{1}$ and she added that

\footnotetext{
A. Kłoskowska, National Cultures at the Grass-Root Level, trans. by Ch.A. Kisiel, Budapest 2001, p. 29.
} 
this process can be depicted as the assimilation and adaptation of cultures genetically different from one's own. ${ }^{2}$

Further on Kłoskowska claims that: National culture is a dynamic system, because it is the product of the creative and receptive actions of people. ${ }^{3}$ Hence, the processes of communication occur not only within the individual systems, but they also take place between two different cultures. This is why, among the mechanisms of the creation and functioning of national cultures, the scholar quoted above singles out (as the fourth of these mechanisms), the expansion of the cultural community beyond the borders of states and nations, ${ }^{4}$ which she names the process of universalization. ${ }^{5}$ Hence, in the context of this study, the presented processes which first occurred in the syntagma of Indian culture apparently expanded beyond the borders of state and nation and they affected the syntagma of Polish culture, undergoing the process of universalization within it.

The functioning and the results of this process, shown on the basis of Rabindranath Tagore's poetic output which functions in this particular sphere of Polish culture, will be presented further on. However, to place the subject of these remarks within the framework of the metaphorical term "cultural syntagma" - created by Kłoskowska to depict a system of any national culture - the main assumptions of her concept need to be recalled. In the aforementioned book, she presents a diagram illustrating the syntagma of a national culture. ${ }^{6}$ The model includes six vertical columns which stand for the main systems of universal symbolic culture, namely language, literature, art, religion, humanities (e.g. knowledge and science) and customs. These six paradigmatic systems are placed on the "syntagmatic axis" of the described diagram. From the vertically placed "paradigmatic axis" horizontal lines are drawn, which cut through the six columns of universal systems, distinguishing the individual entities depicting national cultures, here designated with the term "syntagma." To the syntagma of a national culture, apart from its core composed by the canon, also belong both the "sphere of alienation" of foreign cultures (resulting from "rejection" and "ignorance") and the "sphere of universalization," the product of "affiliation," "adaption" and "assimilation."

The phenomena occurring in the "sphere of universalization" of the syntagma of Polish culture - beginning from the preliminary stage, reception, or "assimilation" of Tagore's poetry - are a rather fascinating example. Especially because the poet's unusual popularity must be one of the most interesting occurrences in the history of reception of Indian literature in Poland.

Ibid.

Ibid., p. 25.

Ibid., p. 26.

Ibid.

6 See: ibid., p. 27.

Kłoskowska admits that in her concept of a syntagma of national culture she uses the idea of French structuralists, especially of Roland Barthes. See: ibid., p. 27. 


\section{TRANSLATIONS AS SYMPTOMS OF LITERARY RECEPTION}

Renderings and translations of Tagore'e poetry into Polish go back to the beginning of the second decade of the $20^{\text {th }}$ century. The first Poles who encountered and translated him where those who studied abroad, mainly in Paris and London. The precursor-translator was apparently Maria Koerner, then a student in Paris, who with the help of a poet D. Mukherjee managed to translate some fragments of Gitanjali directly from Bengali. ${ }^{8}$ The scholars of Tagore's reception ${ }^{9}$ univocally place the earliest mentions of the writer in Polish press and the first excerpts of the translations of his poems between the years 1913-1914. From 1914 onwards Roman Zrembowicz and Jan Kasprowicz began to publish their first attempts. The experts also agree that the turning point was the year 1918, when the volume of translations prepared by Jan Kasprowicz appeared. The collection was titled Gitanjali. Pieśni ofiarne and it contained compositions from three original cycles: The Crescent Moon, The Gardener, and Gitanjali. Song Offerings. The researchers and critics also seem to believe that even though the translations were based not on the Bengali originals but the English self-translations or even self-adaptations of Tagore, Kasprowicz managed to retain the imprints of the Indian spirit. The publication of the volume triggered a lot of activity among the literary critics and essayists, which of course resulted in a considerable number of articles being published on the subject. ${ }^{10}$

The next important date is the year 1921 and the publication of Owocobranie (Fruit-Gathering) translated by Leopold Staff, which among Polish translations is recognized as probably the best, done with an amazing literary culture. ${ }^{11}$ Thanks to this collection, Polish readers could get acquainted with the religious and philosophical stanzas of Tagore. In the following years (1922-1923), the popularity of the Bengali poet in Poland reached its culmination. New translations of prose works - novels, short stories and plays - came out. New translations of previously translated poems also appeared. Articles and studies dedicated to the "Master of the East" were published. It is also worth noting that as in the case of pointing out the definite reasons for the Polish

8 T. Pobożniak, 'Tagore in Poland' in S. Radhakrishnan (ed.), Rabindranath Tagore. A Centenary Volume 1861-1961, New Delhi 1992, p. 348.

9 E.g.: M. Kocięcka, 'Rabindranath Tagore w Polsce' [Rabindranath Tagore in Poland], Przegląd Humanistyczny, No. 4 (1961), pp. 125-134; A. Kowalska, 'Z dziejów recepcji Rabindranatha Tagore'a' [From the History of Rabindranath Tagore's Reception], Przeglad Orientalistyczny, No. 3 (1961), pp. 275-281; T. Pobożniak, 'Tagore in Poland,' pp. 348-355; E. Walter, 'Śantiniketan - gdzie świat miał spotkać się w jednym gnieździe' [Śantiniketan - Where the World was to Meet in One Nest], Kontynenty, No. 4 (1980), pp. 33-34; eadem, 'On Polish Translations of Rabindranath Tagore's Writings' in D. Stasik, A. Trynkowska (eds.), India in Warsaw. A Volume to Commemorate the 50th Anniversary of the Post-war History of Indological Studies at Warsaw University (2003/2004), Warszawa 2006, pp. 100-107; eadem, “'Poczta” Rabindranatha Tagore w Polsce' [Rabindranath Tagore's "Post Office" in Poland], Przeglad Orientalistyczny, No. 1-2 (2011), pp. 3-15.

10 See the bibliography of texts related to R. Tagore in Poland, in A. Kowalska, 'Z dziejów recepcji...'

11 See: A. Kowalska, ibid., p. 267. 
enthusiasm for Tagore and his writings, it seems impossible to establish the reasons why the Polish interest in Tagore's work came to an end. ${ }^{12}$

After World War II, Poles returned to Tagore only towards the end of the 1940s. The Polish Radio, partly inspired by the Polish-Indian Friendship Society, gave a lot of attention to his plays. Additionally, some Indologists from the University of Warsaw made considerable efforts to popularise his work among the Polish audiences. The pre-war translations were republished, all sorts of selections and anthologies containing the previously translated texts also came out. The Polish interest in Tagore's writings, though perhaps a little less enthusiastic than in the 1920s yet still reasonably steady, has continued until the present. ${ }^{13}$

After this brief recapitulation of the history of Tagore's translations into Polish,

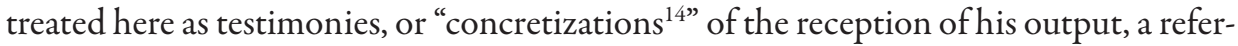
ence needs to be made to a methodological idea of an eminent Polish literary theoretician, Michał Głowiński. In his essay, Świadectwa i style odbioru (Testimonies and styles of reception), he divides the possible methods of reception into five main groups. ${ }^{15}$ Out of these, group four ("all kinds of transformations of a literary work"), in which Głowiński places literary translations, together with transcriptions, will be of interest further on. In his concept, Głowiński classifies translations of a given literature as a symptom of its reception in another culture. In the essay the scholar claims that: [...]

12 Perhaps what happened with regard to Tagore's work in Poland was simply part of a broader "western" phenomenon. For example Amartya Sen states "The enthusiasm with which his work was once greeted was quite remarkable. [...] But he is not much read now in the West, and already in 1937 Graham Greene was able to say: "As for Rabindranath Tagore, I cannot believe that anyone but Mr Yeats can still take his poems very seriously." See: A. Sen, The Argumentative Indian. Writings on Indian Culture, History and Identity, New Delhi 2005, p. 89.

13 Polish translations of Tagore's writings: 1913-1930 - 65 publications (including 38 in the form of a book; no direct translations from Bengali); 1946-2015 - 81 publications (including 23 in the form of a book; among them: 7 anthologies containing pre-war translations and 3 translated directly from Bengali); TOTAL: 146 translations (including 61 books; 3 translated directly from Bengali). Notes, articles, essays, reviews and studies dedicated to Tagore: 1913-1930 - 37 publications; 1946-2011 - 66 publications; TOTAL: 103 publications. (The period between 1930 and 1946 appears to be a gap of 16 years of complete silence in both categories). Total number of publications was calculated on the basis of: A. Kowalska, 'Z dziejów recepcji...'; E. Walter, 'On Polish Translations...'

14 Concretization used here is a term coined by a Polish phenomenologist, Roman Ingarden. Ingarden named and defined the category of concretization in analysing a literary work in 1931, in his work published originally in German, titled Das literarische Kunstwerk (the first edition of its Polish translation came out in 1960, under the title $O$ dziele literackim), long before Hans Robert Jauss, generally regarded as the founder of the theory of reception of literary work, recognized the role of the reader.

15 1. Literary and para-literary statements, in which the process of reading underwent thematization; 2. Meta-literary statements (critical, historical, theoretical); 3. Texts structurally referring to other texts: parodies, stylizations, pastiches; 4 . All kinds of transformations of a literary work: translations, paraphrases, transcriptions; 5. Sociological studies of empirical nature. See: M. Głowiński, Style odbioru. Szkice o komunikacji literackiej [Styles of Reception. Sketches on Literary Communication], Kraków 1977, pp. 116-121. 
every translation, even the most faithful, is an interpretation of a translated work. It is never a loan translation, it remains the domain of choices. ${ }^{16}$ Therefore, it can be assumed that the reception of Tagore's works in Poland - in the same way as the reception of every literary work, including its translations - took place in one, or in several, from among the seven "styles of reception" also detailed by Głowiński. ${ }^{17}$

On the basis of the existing studies and commentaries dedicated to Tagore's oeuvre in Poland, it can be said that two styles of reception are dominant: the allegorical and symbolic styles, occurring together or - much less frequently - separately. The main aim of reading into these texts seems to be revealing either their so-called Indianness or associations to Tagore's own philosophy.

Indeed it may be possible that precisely because his work was read in a very broad context of references and analogies reaching far beyond the realm of arts, Rabindranath Tagore did not become a source of inspiration for the original works of Polish writers. In the context of our national culture, or to be precise: in the realm of literature - his works remain on the level of reception, "assimilation," and in the shape of, even if often beautiful, yet still only translations, created mostly during the time of international (and most certainly pan-European) fashion. ${ }^{18}$

\section{FROM RECEPTION TO CONCRETIZATION}

Among his seven styles of reception Głowiński listed the style of aesthetization, originating from an attempt to receive a literary work mainly as a literary work. The author of the concept states that in the case of this style we could speak of a certain kind of intrinsic literature and that in some cases the idea of the art for the sake of the art becomes the main directive for concretization, while beauty and form become the main categories. The reading concentrates mainly on the work itself and rules out any possible perception of an instrumental nature. The style of aesthetization also seems to correlate with one of Głowiński's methods of reception, e.g. the "transcriptions." This method includes all

16 Ibid., p. 122.

17 Głowiński subsequently classifies and characterises the mythical, allegorical, symbolic, instrumental, mimetic and expressive styles and ends the list with the style of aesthetization. See: ibid., pp. 127-132.

18 In the context of the above statements let us recall the argument raised by the Tagore's experts in Poland that the work and the persona of the poet changed the way of perceiving India in our country, which was earlier formed only by the sources related to the culture of ancient India as well as by the novels of Rudyard Kipling, full of fairytale-like, vivid descriptions of Indian exoticism. Let us also pay attention to the ways in which these experts tried to answer the question about the reasons of Tagore's popularity. For example: "from the very beginning the Indian poet was treated in our country with warmth and friendliness; the simple fact that he was a son of a nation enslaved by foreign imperialism seemed to have been enough to create the atmosphere of heroism - A. Kowalska, ' $Z$ dziejów recepcji..., p. 266. The same scholar also observes that: Literary analysis takes an amazingly small part in most of the reviews and articles written about the Bengali writer, for not from the literary point of view was he arousing the biggest interest. [...] Since Tagore was assumed to be a plenipotentiary representative of Indian culture, it was also believed that "through his lips modern India spoke to the Western world" - ibid., p. 270. 
transpositions of a work from one sign system into another, so in our case from the sign system of a language to the sign system of other arts. ${ }^{19}$

Some unquestionable examples of "transcriptions" may be found in the works of $20^{\text {th }}$ century Polish composers, inspired by the poetry of Rabindranath Tagore. Already in 1918, Karol Szymanowski (1882-1937) composed Cztery pieśni (Four Songs) $O p .41^{20}$ to the words of Tagore's erotic poems from The Gardener. Grażyna Bacewicz (1909-1969) wrote music to two songs by the Bengali poet (in 1936 and 1949). In 1963, Bernadetta Matuszczak (b. 193121) composed Gitanjali na flet, sopran, dzwony i gtos męski recytujacy (Gitanjali for flute, soprano, bells and male reciting voice), and Zbigniew Penherski (b. 1935) created an approximately six-minute-long work, titled 3 recitativi: na sopran, fortepian i perkusje do stów $R$. Tagore (3 recitativi: for soprano, piano and percussion to the words of R. Tagore). The year 1974 brought about a composition by Marek Stachowski (1936-2004), Spiewy thakuryjskie na chór mieszany i orkiestrę (Thakurian chants for mixed choir and orchestra). The works listed above will be further commented on in the next part of this paper. The Almanac of contemporary Polish composers ${ }^{22}$ contains information on three more Polish artists who have compositions inspired by the poetry of Tagore among their works. Jerzy Lefeld (1898-1980) in the years 1921-1923 created the series 4 Songs for voice and piano Op. 4 - one of them to the words of R. Tagore (the other three, to poems by K. Tetmajer, S. Brzozowski and L. Staff). Later, in the years 1947-1948 he wrote 2 Songs for voice and piano Op. 10 to poems by R. Tagore, translated by L. Staff. All three of Tagore's works were selected from Fruit-Gathering. Witold Friemann (1889-1977), in 1925, composed two songs: Victory Op. 47, $\mathrm{nr} 1$ and Indian love-song Op. 47, $\mathrm{nr}$ 2, both selected from The Gardener, one in the translation by Leopold Staff, the other - by Julia Dickstein. The list is concluded by A concerto for soprano and orchestra to the text by R. Tagore, composed in 1963 by Eleonora Grzondziel-Majzel (1921-1993).

Here it is also worth noting that while analysing the processes of assimilation of foreign influences Kłoskowska states: even if the elements of a foreign culture provide the most moving experiences and feeling of closeness, they function as though they had been removed from the context of their origin. Wide and intimate knowledge of the entire national culture constituting their source does not accompany their reception. ${ }^{23}$ Kłoskowska, however, does not judge this phenomenon, therefore it seems justifiable to make the assumption that the reception of a work of art removed from the context of origin is not of a lesser quality than the reception in the source context. Yet, un-

19 See: M. Głowiński, Style odbioru..., pp. 131-132.

$20 \quad 1^{\text {st }}$ edition, Universal Edition, Vienna 1920.

21 The composer's date of birth and the year in which the work was composed quoted after: E. Dziębowska et al. (eds.), Encyklopedia muzyczna PWM [Encyclopaedia of Music], Vol. 6, Kraków 2000, pp. 139-140 (in other sources respectively: 1937 and 1964).

22 M. Hanuszewska, B. Schaeffer, Almanach polskich kompozytorów wspótczesnych [Almanac of Contemporary Polish Composers], Kraków 1982.

23 A. Kłoskowska, National Cultures..., pp. 99-100. 
doubtedly, in such a process the meanings and contexts of the original work undergo concretization. ${ }^{24}$

\section{MUSICAL CONCRETIZATIONS OF TAGORE'S POEMS}

The following examples of concretizations unequivocally testify to the creative and re-creative readings of the works of Rabindranath Tagore in Polish culture. But most of all, they were chosen for their one important quality - all of them are attempts to combine Tagore's verses with musical experiments ${ }^{25}$.

\section{a/ Four Songs Op. 41 by Karol Szymanowski}

Karol Szymanowski's oriental inspirations were the subject of numerous and detailed studies, which have proven that the composer followed some influences of the Eastern poetic and musical traditions, consciously using them to structure his own creative idiom, called the oriental-impressionistic ${ }^{26}$ idiom. In spite of the differences of opinion about the dimension of Szymanowski's relations to the Orient, it is generally acknowledged that the formation process of his individual style, initiated under the Eastern influence, took place in the years 1914-1918, the period during which he composed the music to the four poems by Rabindranath Tagore.

From Tagore's works he chose three poems from The Gardener - My heart, the bird of the wilderness, $O$ mother, the young Prince is to pass by and Then finish the last song to compose four songs. The compositions were written to the texts of German transla-

24 Defined by Roman Ingarden in the following words: Concretization of a literary work, and especially of a literary masterpiece, is an outcome of two different factors: the work itself and the reader but especially his creative and re-creative actions, that he undertakes during the reading - R. Ingarden, Szkice z filozofii literatury [Sketches on Philosophy of Literature], Kraków 2000, p. 67 (Akademia).

25 The examples of musical concretizations of Rabindranath Tagore's poems were also discussed in: R. Czekalska, Wartości autoteliczne w kulturze symbolicznej. Na przyktadzie indyjsko-polskich spotkań literackich [Intrinsic Values in Symbolic Culture. On the Example of Indo-Polish Literary Encounters]. Kraków: Księgarnia Akademicka 2013. Series: Societas 75.

26 In the article 'Szymanowski and Literature,' while analysing this issue, Jarosław Iwaszkiewicz, one of the greatest Polish writers and also the composer's cousin, wrote: He selects texts from Hafiz, Mevlana Djelaleddin Rumi, from Rabindranath Tagore. [...] From the literature point of view they could be of various genres, but these works are connected by some common qualities; all of them are characterised by a certain astonishing, distinctive mysticism -J. Iwaszkiewicz, 'Szymanowski a literatura' [Szymanowski and Literature] in Karol Szymanowski. Księga sesji naukowej poświęconej twórczości Karola Szymanowskiego, Warszawa 23-28 Marca 1962 [Karol Szymanowski. Proceedings Volume of the Academic Seminar Dedicated to Karol Szymanowski’s Oeuvre, Warsaw March 23-28, 1962], Warszawa 1964, p. 129 (Prace Instytutu Muzykologii Uniwersytetu Warszawskiego). Iwaszkiewicz assumes that the composer's goals? at this stage of his artistic development were autonomous and independent from outside factors. He also does not explain what he meant by the "astonishing mysticism" and does not dwell on the question of the Oriental provenience of the works. He seems to be convinced that neither the "eastern-ness" nor the "exoticism" of the texts were the reason of them being selected by Szymanowski, but rather the mystical as well as erotic meanings contained in the poems. 
tions by Hans Effenberger (which were prepared on the basis of Tagore's own English translations). The Polish renderings, based on Effenberger's translations, were done by Jarosław Iwaszkiewicz.

Thanks to a letter sent by the composer to the author of the texts, it is known that the question of "accent" and metre was to Szymanowski most definitely of primary importance. ${ }^{27}$ Presumably, this is why the length and the arrangement of the poems create a complete rhythmical compositional structure (short-long-long-short: 8 lines-11 lines-12 lines-7 lines) and the length of the compositions by Szymanowski corresponds with the length of the poems. The works are characterised by simple sounds, harmonising with the poetic texts. While listening, one could get the impression that the music adapts itself to the melody and the expressiveness of the words and, similarly to classical Hindustani music, the musical instruments follow the voice of the singer as if they were imitating it. Another possible reference to Indian music are the fragments of the notation for the piano in The young Prince I, where the strokes of the keys appear to resemble the rhythmical beats of a small drum (described in the score as: staccato quasi il piccolo tamburo). Even though Polish musicologists hear the sounds of the Arabic drum ${ }^{28}$ there, it might as well be a kettledrum, or perhaps a remote variation on the use of the tabla as an instrument dictating the rhythmical pattern.

Furthermore, with reference to Indian aesthetics, it could be said that in a manner of speaking the selected poems also constitute a complete story, they describe the subsequent moods of love: longing, reunion, misunderstanding, grief, disappointment. And these moods are also rendered in Szymanowski's compositions.

\section{b/ Speak to me, o my love and Separation by Grażyna Bacewicz}

The great Polish composer and violinist has two compositions inspired by the poetry of Rabindranath Tagore in her incredibly rich output. These are songs written to the poems Speak to me, my love and Then finish the last song selected from The Garden$e r$. The first song was composed in 1936, the second - in 1949. Both were written for the piano. According to one of the possible classifications, in which the songs of Bacewicz were divided into three groups, the compositions to Tagore's poems are in-

27 The composer wrote to his cousin, the poet: I beg of you, do not deny me your Polish translations of these 4 lyrics by Tagore - I must send these songs for print as soon as may be - and I wouldn't like to send them without the Polish text. [...] I would very much wish for the translation to be faithful in prosody (metrically). [...] Moreover, if it is at all possible, the crucial words (with the psychological accent), to fall in identical places -K. Szymanowski, Korespondencja. Petna edycja zachowanych listów od i do kompozytora [Correspondence. A complete Edition of Extant Letters from and to the Composer], Vol. 1: 1903-1919, ed. T. Chylińska, Kraków 1982, p. 616 (letter dated: 18 August 1918).

28 See: A. Nowak, 'Rabindranath Tagore i pieśń polska. O inspiracji Orientem' [Rabindranath Tagore and the Polish Song. On the Inspiration by Orient] in Inspiracje w muzyce XX wieku - filozoficzno-literackie, religijne, folklorem. Materiaty Ogólnopolskiej Konferencji Muzykologicznej 1-3 października 1993 Podkowa Leśna [Inspirations in $20^{\text {th }}$ Century Music - Philosophical, Literary, Religious, Folkloristic; Proceedings of the All Poland Musicological Conference, October 1-3, 1993 Podkowa Leśna], Warszawa 1993, p. 49. 
cluded in the first group, comprising lyrics dedicated to love matters, in which a woman is an important presence. ${ }^{29}$

Some experts on Bacewicz's work point out the obvious possibility of an indirect inspiration - the interest in Tagore's poetry triggered by Szymanowski's compositions. This possibility cannot of course be ruled out. In this context it may be worth noting that Separation, the latter of the two songs, was composed, like The last song of Szymanowski, to Tagore's Then finish the last song. However, the two compositions differ greatly. This is due to, firstly, the Polish texts, as they were translated by two different poets (Kasprowicz and Iwaszkiewicz), and secondly the tempo of both the pieces, and in consequence their moods. Bacewicz marked her score Allegretto, whereas the disposition of Szymanowski reads - Lento assai, Mesto.

There is also one more distinctive feature of both the songs by Bacewicz. They were composed to the translations by Jan Kasprowicz that are characterised by free versification. Perhaps this is why keeping to the syntactic structures and natural intonation of sentences in these songs seems more important than following any rhythmical pattern.

And even though it is possible that searching for the sources of inspiration may bring no result - also because of the fact that they are not always found in full awareness - in Polish music, the "oriental" lyrics of Bacewicz will remain a special case of the encounter of two different cultural traditions within the sphere of universal ideas, and the expression of a universalistic attitude that values in art what is durable, constant and universal. ${ }^{30}$

\section{c/ Gitanjali for flute, soprano, bells and male reciting voice by Bernadetta Matuszczak}

The composer, who is described by the critics as a deeply spiritual author of contemporary religious compositions, made her debut in 1963 - one year before obtaining a diploma in composition - with a work inspired by poems from Gitanjali. She chose seven poems from Tagore's collection (Thou hast made me endless..., When thou commandest me to sing..., I know not how thou sing, my master!.... My song has put off her adornments..., I am only waiting for love..., Early in the day..., I know that the day will come...), translated by Jan Kasprowicz. However, in her notation the author does not in any way mark the beginnings of the separate songs, creating one long vocal and instrumental composition. ${ }^{31}$

29 Eadem, 'Pieśni solowe Grażyny Bacewicz' [Grażyna Baczewicz’s Solo Vocal Compositions] in M. Gąsiorowska (ed.), O Grażynie Bacewicz. Konferencja muzykologiczna "Grażyna Bacewicz - cztowiek i dzieto," Warszawa, 9-10 stycznia 1989 roku, Sekcja Muzykologów Związku Kompozytorów Polskich. Materiaty z konferencji muzykologicznej [On Grażyna Bacewicz. "Grażyna Bacewicz - the Person and the Work," Proceedings of a Musicological Conference], Warszawa 1998, p. 121.

30 See: ibid., p. 133.

31 I am grateful to Ms. Aneta Derkowska for the deatiled information regarding the choice of Tagore's work in Matuszczak's composition. 
It may have been that the mystical and religious themes contained in Tagore's works caught the attention of the young artist. Perhaps this fascination was also a sign of her developing deep interest in religious subjects, which resulted in Apocalypsis according to St. John, among other compositions.

The fact that the composer - with confirmed, complex interests in literature -began her artistic carrier with a work inspired by Tagore is also rather meaningful, since Gitanjali for flute, soprano, bells and male reciting voice opens an impressive list of works created through literary inspirations, among which can be found, for example, Juliet and Romeo (chamber opera) or Songs of Rilke (for baritone and orchestra).

\section{$\mathrm{d} / 3$ Recitativi... to the words of R. Tagore by Zbigniew Penherski}

Zbigniew Penherski is described as an artist with a clear, powerful personality, who perceives the world and art in the most individual manner. In these features, the critics seek the reasons of his interest in different, exotic cultures, which are treated as potential sources of inspiration. This might also be the possible cause of the Tagorean motif's presence in his output. Penherski is a representative and a follower of sonorism, and the 3 Recitativi for soprano, piano, percussion to the words of $R$. Tagore belong precisely to his sonorist ${ }^{32}$ compositions. The composition was written to three pieces by Tagore, The touch of the nameless days, The music of the far-away summer and Stray birds, from the collection Stray birds, translated into Polish by Robert Stiller. The work was published in 1977, in the series Contemporary Polish Music. The Series of Solo Compositions. In the composition, perhaps following the pattern of the vocal music of North India, the composer seems to give a special importance to the human voice - treated by him as one of the musical instruments. Therefore, in the directions for the performers he included a meaningful remark: the note /or notes/ [...] are to be performed as differently as possible from the prevailing metre. ${ }^{33}$

The composer characterises his own music in the following manner: The form for me is extremely important, but always it is my own form. If I looked for references, they would be to architecture and mathematics. [...] I believe that my early works are almost of the same style as the last ones. I aspire to have my own language to which, I think, I remain faithful..$^{34}$ In the case of the meaning conferred by Tagore's verses, Penherski certainly expressed it with a language of his own.

32 Sonorism - a style of musical composition that focuses on the characteristics and qualities of sound to create form. It is primarily associated with an unconventional and experimental musical movement which arose in Poland in the mid 1950s and flourished through the 1960s.

33 See: Z. Penherski, 3 recitativi: na sopran, fortepian, perkusję do stów R. Tagore [3 Recitativi: On Soprano, Piano, Percussion to the Words of R. Tagore], Warszawa 1977, note 5, p. 5 (Wspótczesna Muzyka Polska. Seria Utworów Solistycznych).

34 Source: 'Zbigniew Penherski,' Polskie Centrum Informacji Muzycznej, at <http://www.polmic.pl/index.php?option=com_mwosoby\&Itemid=4\&id=54\&view=czlowiek $>, 15$ July 2012. 


\section{e/ Thakurian Chants for mixed choir and orchestra by Marek Stachowski}

The output of this composer is described as a work of great diversity of styles and genres. The experts also highlight the philosophical content of his entire oeuvre, and his extra-musical, poetic inspirations. "Exotic cultures" are also listed among these inspirations, an example of which is the symphonic long poem titled Thakurian Chants for mixed choir and orchestra, composed in 1974 and awarded in the Karol Szymanowski Competition.

The vocal symphonic work of Stachowski is composed of six parts. It was written to three complete poems and one fragment, selected from the volume Lover's Gift \& Crossing. The incipits of the selected poetic pieces are: Some one has secretly ${ }^{35} \ldots$... Free me..., Rejoice!... and There are numerous strings... The composition belongs to the sonorist period of Stachowski's carrier and is supposed to be an outcome of a reference to Indian Orient, which is musically interpreted in the most contemporary manner. ${ }^{36}$ This remark, made by a musicologist, also testifies to the fact that Tagore's poetry once again became a source of inspiration for the Polish avant-garde music of the second half of the $20^{\text {th }}$ century.

\section{THE UNIVERSALISING POWER OF INSPIRATION}

Undoubtedly, the Polish composers' reaction to Tagore's poetry was of a creative nature. They composed vocal and instrumental works to the poetic texts. But all of them also wrote music to the poems of other authors. Should the "Tagore case" be therefore treated as a unique phenomenon?

Polish philosopher Władysław Stróżewski defines the complex phenomenon of inspiration in the following words: By inspiration I understand a particular kind of agitation of our senses of perception and also our creative possibilities, through something that has a certain content, that is experienced as external, not coming from us, yet which convinces us to give it a creative response. ${ }^{37}$ Moreover, literary inspirations in vocal music do not in any case astonish Głowiński who states that where the vocal compositions are concerned the cohabitation with all kinds of literary genres is only natural..$^{38}$

On the other hand, the observations of the musicologists engaged in researching the Tagorean inspirations in Polish music seem to be heading towards the conclusion that in the case of texts belonging to such a distant culture, there is some room if not for astonishment, then at least for reflection on the depth and the scope of such inspirations.

35 Spelling follows the original.

36 See: A. Hejmej, 'Literackie inspiracje kompozytora' [The Composer's Literary Inspirations] in L. Polony (ed.), Marek Stachowski i jego muzyka, Kraków 2007, p. 34.

37 See: W. Stróżewski, 'O pojęciu inspiracji' [On the Notion of Inspiration] in Inspiracje w muzyce XX wieku..., p. 141.

38 M. Głowiński, 'Gatunki literackie w muzyce' [Literary Genres in Music] in Inspiracje w muzyce XX wieku..., p. 16. 
They also draw attention to the fact that when it comes to music, they either do not notice these influences at all, or notice only their very slight echoes. In their view, the compositions apparently only rely on the universal content of the poems. ${ }^{39}$

\section{CONCLUDING REMARKS}

As we can find out from his numerous declarations, to Rabindranath Tagore music and poetry were inseparable. He used to prophesize that even if his poetry does not survive, the music he has created will certainly remain. Therefore, the phenomenon of inspiration with the works of the Bengali poet - that happened to the Polish composers - lies not only in the fact that they consciously, or through intuition, returned to his poetry even though it was long out of fashion, but most of all in the undisputable fact that, by doing so, they enriched and refreshed their own aesthetics. ${ }^{40}$

Moreover, the fascinating quality of this phenomenon seems to lie in the fact that the very same poetic texts which, in the first half of the $20^{\text {th }}$ century, were recognized as unusually modern in India, and which in Poland, through their translations, artistically followed the patterns of traditional poetics (even though one of the translators, Julian Przyboś, was an avant-garde poet), after some years became an inspiration for the avant-garde musical compositions.

In this way the self-prophecy of Rabindranath Tagore became reality - the music he infused in his poetry remained and, through their musical quality, his poems gained a new life in the works of contemporary Polish composers. Consequently, the history of Tagor's poetic oeuvre came full circle: from the moment it was created as poetry with an innate, clearly musical dimension, to the moment of its universalization through musical concretizations in the syntagma of a foreign culture.

\section{BIBLIOGRAPHY}

Czekalska R., Wartości autoteliczne w kulturze symbolicznej. Na przyktadzie indyjsko-polskich spotkan literackich [Intrinsic Values in Symbolic Culture. On the Example of Indo-Polish Literary Encounters]. Kraków: Księgarnia Akademicka 2013. Series: Societas 75.

Derkowska A., Muzyka i stowo w twórczości Bernadetty Matuszczak, Toruń 2005.

Dziębowska E. et al. (eds.), Encyklopedia muzyczna PWM [Encyclopaedia of Music], Vol. 6, Kraków 2000.

39 Setting borderlines in the sphere of cultural inspiration appears to be incredibly difficult, especially in the light of the previously quoted essay by Stróżewski, in which the phenomenon of inspiration is characterised as follows: Probably the most important moment in the experience of inspiration is the particular dialectics of "exteriority" and "interiority." That what inspires, whether as a content, whether as a certain kind of "calling," is experienced as something that comes, or "comes over" us, independent from us and not belonging to us - W. Stróżewski, 'O pojęciu inspiracji,' p. 136.

40 See: D. Gwizdulanka, 'Inspiracja w muzyce kameralnej XX wieku' [Inspiration in $20^{\text {th }}$ Century Chamber Music] in Inspiracje w muzyce XX wieku..., p. 89. 
Głowiński M., 'Gatunki literackie w muzyce' [Literary Genres in Music] in Inspiracje w muzyce XX wieku - filozoficzno-literackie, religijne, folklorem. Materiaty Ogólnopolskiej Konferencji Muzykologicznej, 1-3 października 1993 Podkowa Leśna [Inspirations in 20 ${ }^{\text {th }}$ Century Music - Philosophical, Literary, Religious, Folkloristic; Proceedings of the All Poland Musicological Conference, October 1-3, 1993 Podkowa Leśna], Warszawa 1993.

Głowiński M., Style odbioru. Szkice o komunikacji literackiej [Styles of Reception. Sketches on Literary Communication], Kraków 1977.

Gwizdulanka D., 'Inspiracja w muzyce kameralnej XX wieku' [Inspiration in $20^{\text {th }}$ Century Chamber Music] in Inspiracje w muzyce XX wieku - filozoficzno-literackie, religijne, folklorem. Materiaty Ogólnopolskiej Konferencji Muzykologicznej 1-3 października 1993 Podkowa Leśna [Inspirations in $20^{\text {th }}$ Century Music - Philosophical, Literary, Religious, Folkloristic; Proceedings of the All Poland Musicological Conference, October 1-3, 1993 Podkowa Leśna], Warszawa 1993.

Hanuszewska M., Schaeffer B., Almanach polskich kompozytorów wspótczesnych [Almanac of Contemporary Polish Composers], Kraków 1982.

Hejmej A., 'Literackie inspiracje kompozytora' [The Composer's Literary Inspirations] in L. Polony (ed.), Marek Stachowski i jego muzyka, Kraków 2007.

Ingarden R., Szkice z filozofii literatury [Sketches on Philosophy of Literature], Kraków 2000 (Akademia).

Iwaszkiewicz J., 'Szymanowski a literatura' [Szymanowski and Literature] in Karol Szymanowski. Księga sesji naukowej poświęconej twórczości Karola Szymanowskiego, Warszawa 23-28 Marca 1962 [Karol Szymanowski. Proceedings Volume of the Academic Seminar Dedicated to Karol Szymanowski’s Oeuvre, Warsaw March 23-28, 1962], Warszawa 1964 (Prace Instytutu Muzykologii Uniwersytetu Warszawskiego).

Kłoskowska A., National Cultures at the Grass-Root Level, trans. by Ch.A. Kisiel, Budapest 2001.

Kocięcka M., 'Rabindranath Tagore w Polsce' [Rabindranath Tagore in Poland], Przegląd Humanistyczny, No. 4 (1961).

Kowalska A., 'Z dziejów recepcji Rabindranatha Tagore'a' [From the History of Rabindranath Tagore's Reception], Przegląd Orientalistyczny, No. 3 (1961).

Nowak A., 'Pieśni solowe Grażyny Bacewicz' [Grażyna Baczewicz’s Solo Vocal Compositions] in M. Gąsiorowska (ed.), O Grażynie Bacewicz. Konferencja muzykologiczna "Grażyna Bacewicz - cztowiek i dzieto," Warszawa, 9-10 stycznia 1989 roku, Sekcja Muzykologów Związku Kompozytorów Polskich. Materiaty z konferencji muzykologicznej [On Grażyna Bacewicz. "Grażyna Bacewicz - the Person and the Work," Proceedings of a Musicological Conference], Warszawa 1998.

Nowak A., 'Rabindranath Tagore i pieśń polska. O inspiracji Orientem' [Rabindranath Tagore and the Polish Song. On the Inspiration by Orient] in Inspiracje $w$ muzyce XX wieku filozoficzno-literackie, religijne, folklorem. Materiaty Ogólnopolskiej Konferencji Muzykologicznej 1-3 października 1993 Podkowa Leśna [Inspirations in 20 th Century Music - Philosophical, Literary, Religious, Folkloristic; Proceedings of the All Poland Musicological Conference, October 1-3, 1993 Podkowa Leśna], Warszawa 1993.

Penherski Z., 3 recitativi: na sopran, fortepian, perkusję do stów R. Tagore [3 Recitativi: On So- 
prano, Piano, Percussion to the Words of R. Tagore], Warszawa 1977 (Wspótczesna Muzyka Polska. Seria Utworów Solistycznych).

Pobożniak T., 'Tagore in Poland' in S. Radhakrishnan (ed.), Rabindranath Tagore. A Centenary Volume 1861-1961, New Delhi 1992.

Ray M.K. (ed.), The English Writings of Rabindranath Tagore, Vol. 8: Miscellaneous Writtings, New Delhi 2007.

Sen A., The Argumentative Indian. Writings on Indian Culture, History and Identity, New Delhi 2005.

Sosnowski M., Rabindranath Tagore. Osoba iznaczenie [Rabindranath Tagore. The Persona and Stature], Warszawa 2007.

Stróżewski W., 'O pojęciu inspiracji' [On the Notion of Inspiration] in Inspiracje w muzyce XX wieku - filozoficzno-literackie, religijne, folklorem. Materiaty Ogólnopolskiej Konferencji Muzykologicznej 1-3 października 1993 Podkowa Leśna [Inspirations in 20 ${ }^{\text {th }}$ Century Music - Philosophical, Literary, Religious, Folkloristic; Proceedings of the All Poland Musicological Conference, October 1-3, 1993 Podkowa Leśna], Warszawa 1993.

Szymanowski K., Korespondencja. Petna edycja zachowanych listów od i do kompozytora [Correspondence. A complete Edition of Extant Letters from and to the Composer], Vol. 1: 1903-1919, ed. T. Chylińska, Kraków 1982.

Walter E., "Poczta” Rabindranatha Tagore w Polsce' [Rabindranath Tagore's "Post Office” in Poland], Przegląd Orientalistyczny, No. 1-2 (2011).

Walter E., 'On Polish Translations of Rabindranath Tagore's Writings' in D. Stasik, A. Trynkowska (eds.), India in Warsaw. A Volume to Commemorate the 50th Anniversary of the Post-war History of Indological Studies at Warsaw University (2003/2004), Warszawa 2006.

Walter E., 'Śantiniketan - gdzie świat miał spotkać się w jednym gnieździe' [Śantiniketan Where the World was to Meet in One Nest], Kontynenty, No. 4 (1980).

'Zbigniew Penherski,' Polskie Centrum Informacji Muzycznej, at <http://www.polmic.pl/index.php?option $=$ com_mwosoby\&Itemid $=4 \&$ rid $=54 \&$ view $=$ czlowiek $>$.

Renata CZEKALSKA, Ph.D. - Associate Professor at the Institute of the Middle and Far East, Jagiellonian University, Krakow, Poland. She specializes in South Asian culture, the modern history of South Asia, and intercultural communication. Her recent publications include a hermeneutic analysis of the main thematic structures in the poetry of Ashok Vajpeyi, and a monograph dedicated to the enriching phenomenon of mutual transfer of intrinsic values in symbolic cultures. 